\title{
The Nexus between Political \& Institutional Corruption Events with the Stock Market: A Study of Pakistan
}

\author{
Shamrez Ali * Sundus Waqar ${ }^{\dagger} \quad$ Muhammad Haris $\ddagger$
}

\begin{abstract}
Arrival of new information and dissemination of that information in asset prices is the determining force of asset returns. This paper studies the nexus between political and institutional corruption events with daily stock market returns by using Mega Corruption cases that were reported between January 2011 to February 2019. Therefore, to study how stock market returns react to these selected events, a mean adjusted model has been applied and a before and after, two and five day event window has been constructed. The results show that political and institutional corruption events have negative and significant impact on stock market returns. Hence, the paper concludes that investors and portfolio managers should be prudent towards their investment decisions during times of uncertainty.
\end{abstract}

Keywords: Corruption, stock market, political stability, volatility.

\section{Introduction}

Stock Exchange has a significant role in the advancement of any economy (Perveen \& Rahman, 2017). An effectual stock exchange provides the general public a platform to utilize their savings and provides industrialists a platform to raise capital efficiently (Gul, Khan, Saif, Rehman, \& Roohullah, 2013). Mohtadi and Agarwal (2001) conclude that the overall economic conditions are a reflection of the stock market condition and they report that improved stock market performance fuels economic growth. Therefore, business analyst and investors consider stock market to be a key representation of a country's economic condition. While, recently capital market activity has risen on a global scale (Pakistan Economic Survey, 2019), financial products have become more complex and financial markets more volatile. Therefore, the importance of the stock market coupled with the increased uncertainty makes investigation of stock market movements a crucial topic that requires utmost attention.

Arrival of new information and dissemination of that information in asset prices is the determining force of asset returns (Glosten \& Milgrom, 1985; Chua \& Tsiaplias, 2019). The interrelationship between news and asset volatility is well established in past theory (Ross, 1989). Economic growth is dampened not by continuous price changes but rather due to occasional and large price jumps (Li, Li, \& Zhou, 2015). The importance of price jumps can be discerned that it was at the focal point of the financial crisis of 2008 .

\footnotetext{
*M.Phil Economics, Quaid-e-Azam University, Islamabad. E-mail: ashamrez51@yahoo.com

${ }^{\dagger}$ Msc Finance and Investment, Nottingham University, Malaysia Campus. E-mail: ksax6sww@nottingham.edu.my

${ }^{\ddagger}$ Bank Al-Habib. E-mail: m.haris515@yahoo.com
} 
Understanding of shocks in the financial market is of paramount significance because it contributes to non-diversifiable risk in portfolios and its understanding will enable policy makers to develop appropriate strategies during economic turmoil (Gupta, Lau, Liu, \& Marfatia, 2019).

According Bilson, Brailsford, and Hooper (2002) other asset pricing factors like systemic risk, interest rate risk and default risk have been extensively studied but political risk has relatively had less attention. Political stability is a very important factor which significantly affects many business sectors, both local and international. Foreign investors prefer investment opportunities in the form of portfolio investments or foreign direct investment (FDI) in countries that have stable political conditions (Rawat \& Arif, 2018). Barro and Lee (1994) deduced that economic growth is hampered due to political vulnerability of a country.

Furthermore, political stability is a crucial aspect that has an influence on capital market performance; many researchers find a significant link between stock market effectiveness and political events. A stable political environment creates strong financial and economic conditions. Investors are squeamish when it comes to investing in unstable political conditions because the unforeseen events disturb the market and increase its volatility (Irshad, 2017). Beaulieu, Cosset, and Essaddam (2005) concluded that as a firm becomes more susceptible to political risk, it's stock return volatility also increases. Niederhoffer (1971) conducted his research and concluded that world events significantly influenced the S\&P Index. Likewise, Karachi Stock Exchange (KSE) crashed after assassination of Benazir Bhutto in 2007 (Hassan, Mahmood, Ahmed, \& Abbas, 2014), the stock market also crashed after Nawaz sharif disqualify in Panama gate corruption charges in 2017 (DAWN, 2017). However, Cutler, Poterba, and Summers (1989) investigated how stock prices responded from 1941 until 1987 to forty-nine non-economic global news and found a "surprisingly small effect".

There are different factors that are responsible for political instability such as law \& order situation, changing government, corruption in government institutions and so on. These factors and their intensity vary from country to country. However, studies have been centric to developed countries rather than developing countries. Developing countries usually have more rigid and less liberal political and economic regimes with more uncertain policies and outcomes. Consequently, in developing markets, political uncertainty is a crucial determining factor in asset prices (Bin, 2015). Therefore, in this paper we study the nexus between political and institutional corruption events with the stock market of a developing country, Pakistan, and to the best of our knowledge we are the first one to do so.

Former studies investigated the linkages of stock market with different factors and sectors, but there is scanty literature that looks at stock market performance with respect to political and institutional corruption events. Corruption is defined as the misuse of one's office power for their own benefit (Collins, Uhlenbruck, \& Rodriguez, 2009). There are two opposing arguments on how corruption impacts economic growth. On the one hand, many scholars agree that economic growth is hampered by the negative influence of corruption (Shleifer \& Vishny, 1993), while on the other hand, scholars argue that the impact is positive (Egger \& Winner, 2005). 
There are many scholars ascertaining that corruption sands the wheel. Corruption decreases competition in the domestic market, makes foreign operations difficult and attaining license becomes cumbersome (Cuervo-Cazurra, 2008). Shleifer and Vishny (1993) argue that corruption leads to wastage as it increases transaction costs in the economy and managers may take on less feasible projects. Corruption creates a non-conducive environment that restricts FDI inflows and stock market development (Voyer \& Beamish, 2004). Additionally, Ayaydin and Baltaci (2013) used forty-two developing countries and created a panel for the period 1996 to 2011 and found corruption to negatively impact the advancement of capital markets.

In Pakistan, corruption is one of the dire problems that need immediate attention. In 1996, Pakistan was ranked as the second most corrupt economy by Transparency International (TI). Due to the report, Pakistan's image was tarnished and foreign donors and investors were discouraged to invest in a country where bribery and money laundering was widespread. Also, Sohail Muzaffar, Chairman of TI Pakistan, said that the economic condition of Pakistan cannot be improved until corruption is controlled. According to 2018, Corruption Perception Index (CPI) rating which ranks countries based on comparative levels of corruption, Pakistan ranks 117 out of 180 countries with a score of 33 (with 0 being highly corrupt and 100 very clean).

Continuous efforts are being made to tackle the menace. In 1999, General Pervaiz Musharraf revealed his agenda that incorporated accountability on every level. Later, the National Accountability Ordinance (NAO) and National Accountability Bureau (NAB) were formed. NAO is to date the most extensive legislation related to corruption and $\mathrm{NAB}$ is an anti-corruption agency. NAO gives the head of NAB unprecedented rights such as non bailable arrest warrants, property freezing and 14 years of imprisonment as punishment. Currently, the President of Pakistan, Imran Khan is focused on eradicating corruption from the country. In a parliament session, he highlighted that grouping interests and corruption are two major reasons that are hindering the country's growth. Moreover, he promised to bring about a system without corruption. In its aftermath, there have been continuous corruption charges against prominent bureaucratic and political figures such as Asif Zardari and Nawaz Sharif.

Therefore, in this paper, we study whether these spree of events had an impact on the stock market or not. The remaining paper is organized as follows: the next section discusses the methodology used which includes the research model, sample size and research technique. The next section reports and analyses the results. Lastly, the paper concludes with discussion and policy recommendations.

\section{Methodology}

\section{Research Model}

This paper studies the impact of political \& institutional corruption events on equity market returns. There are lots of historical corruption events that are associated with elected and selected members of assembly, but there are also a number of corruption events that 
are associated with government officers. Therefore, it is necessary to include institutional corruption events along with political corruption events. Hence, the scope of this study is to measure the change in stock market returns in the response of those political and institutional corruption events that occurred during January 2011 to February 2019. Our model is as follows:

\section{StockReturn $=f($ Corruptionevents)}

Based on past literature, we postulate that corruption news will have a significant effect on the stock market.

\section{Sample Size}

The time series data of stock market daily return and corruption events is 08 years and 02 months from January 2011 to February 2019. This period is when The Government of Pakistan shifted from dictatorship to democracy and many mega corruption cases were filed by NAB. To capture the response of the stock market, this study uses daily returns of KSE 100 index by constructing event windows of 2 and 5 days before and after the event occurrence. Furthermore, for political and institutional corruption events, only those events are included which are considered as mega corruption cases. These events were published in well recognized daily newspapers namely, "Dawn News", "Nation", "The News" and "Pakistan Today". The criteria of selection for the corruption events are its nature and worth.

\section{Research Technique}

In this research, Mean Adjusted Return Model is being used to estimate the normal and expected return of Karachi Stock Market in the 02 and 05 days event window. Mean adjusted return model is one of the preferred techniques for studying market indexes by the effect of different events before and after its occurrence.

$$
R^{*}=(1 / T) \sum_{(t=1)}^{t} R_{t}
$$

Here,

$R^{*}$ constant represent the expected return of the index

$T$ is the number of days

$R_{t}$ is the market index return on the day

Expected return is subtracted from actual return to calculate the abnormal market return of the index.

Therefore, 


$$
A R_{t}=R_{t}-R^{*}
$$

Now we calculate the average abnormal return for event window $02 \& 05$ days before the event is, Average abnormal return for the event window 02 \& 05 days after the event is,

$$
A R_{\text {before }}^{*}=\sum_{t=-k}^{t=-1} A R_{\text {before }, t / n}
$$

Average abnormal return for the event window $02 \& 05$ days after the event is,

$$
\begin{gathered}
A R_{\text {after }}^{*}=\sum_{t=k}^{t=1} A R_{\text {after }, t n} \\
\sigma_{\text {before }}=\sqrt{\sum_{t=-k}^{t=-1}\left(A R_{\text {before }}-A R *_{\text {before }}\right)^{2} /(n-1)}
\end{gathered}
$$

And;

$$
\sigma_{a f t e r}=\sqrt{\sum_{t=k}^{t=1}\left(A R_{a f t e r}-A R *_{a f t e r}\right)^{2} /(n-1)}
$$

Then;

$$
\sigma_{\text {before-after }}=\sqrt{\left(n_{1}-1\right) \sigma_{1}^{2}+\left(n_{2}-1\right) \sigma_{2}^{2} /\left(n_{1}+n_{2}-1\right)}\left(1 / n_{1}+1 / n_{2}\right)
$$

Now we have,

$$
t=\left(A R *_{\text {after }}-A R *_{\text {before }}\right) / \sigma_{\text {pre-post }}
$$

Where $\sigma$ is the variance of event period, hence if the value of the t-statistic is significant than market is inefficient and influenced by the corruption events and if $t$-statistics show insignificant result then market is efficient and not influenced by the corruption events.

\section{Empirical Studies}

Following are the results found shown in (table I) by applying the mean adjusted return model on the particular political corruption events by taking significance level at $10 \%$. 


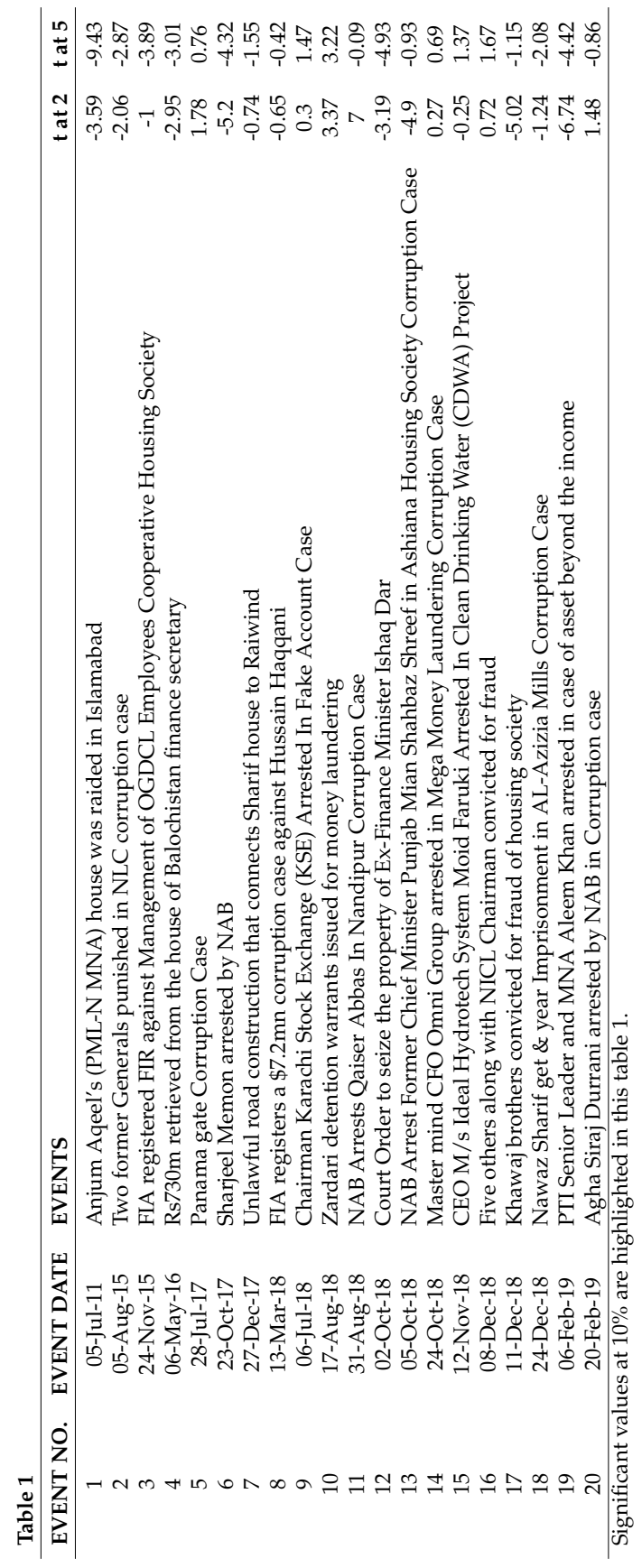




\section{Empirical Results}

\section{Anjum Aqeel's (PML-N MNA) House was Raided in Islamabad}

According to the news of "DAWN" on 05 July 2011, Mr. Aqeel Anjum escaped when his residence was raided by the Islamabad police in the corruption case of National Police Foundation (NPF) worth 6 billion of land Acquired for NPF. The statistical results show that the $t$-value for this event is significant and negative. Investors took this information negatively due to which stock market crashed badly for both short and long event windows.

\section{Two Former Generals Punished in NLC Corruption Case}

According to the News of "DAWN" on 5 Aug 2015, Lt Gen (retd) Muhammad Afzal Muzaffar and Major General (Retd) Khalid Zahir Akhter were convicted in the National Logistics Cell (NLC) corruption case under the Pakistan Army Act. They illegally invested Rs 4300 million in shares, which resulted in the loss of Rs 1800 million to the organization. The empirical result shows that this corruption news significantly affected the stock market, the t-value for both the 2 days and 5 days event window shows a significant and negative impact on the stock exchange which means this event reduced stock market returns.

\section{FIA Registered FIR against Management of OGDCL Employees Cooperative Housing Society}

According to the news of "The Nation" on 24 Nov 2015, a first information report (FIR) was recorded against five people by the Federal Investigation Agency (FIA). Three of the five employees worked at Oil and Gas Development Company Limited (OGDCL) and they were charged for being fraudulent in OGDCL Employees Housing Society. It is reported that they embezzled Rs 570 million. The $t$ value for the long event window shows a significant and negative relationship between this corruption event and stock market performance, and an insignificant $t$ value was found in the short event window.

\section{Rs730 m Retrieved from the House of Balochistan Finance Secretary}

According to the news of "DAWN" on 06 May 2016, NAB retrieved Rs730m from the house of Balochistan finance secretary, Mushtaq Ahmed Raisani and recovered corruption money worth $730 \mathrm{~m}$ including local currency, foreign currency, bonds and jewelry. She has been charged for misusing development funds of the local government worth billions of rupees. It is observed that this event has a significant negative impact on the stock market in both, short and long runs.

\section{Panama Gate Corruption}

According to the news of "Dawn" on July 28 2017, three times Prime Minister of Pakistan, Mian Nawaz Sharif was disqualified on Panama gate Corruption charges, and it is noted 
that the stock market quickly responded to this event and KSE 100 index fall to 700 points within a minute of court verdict. The statistical result shows that stock become inefficient in the short period of time but it absorbed this event very soon and after 2 to 3 days stock market started to recover its position and become efficient in 5 day event window.

\section{NAB arrested Sharjeel Memon}

According to the news of "DAWN" on 23 Oct 2017, NAB arrested PPP Leader and Former Information Minister of Sindh, Sharjeel Memon, and 12 other accused. They were involved in the case of advertisement corruption practices as they charged too high rates, worth 5.76 billion. The statistical result shows a significant negative effect of this event on the stock market performance in both the $02 \& 05$ days event window. Stock market became inefficient after this corruption event and the impact continued throughout the week.

\section{Unlawful Road Construction that Connects Sharif House to Raiwind}

According to the news of "Pakistan Today" on 27 Dec 2017, a reference was filed against Nawaz Sharif, Shahbaz Sharif and others by the NAB executive board. The charge was an Unlawful road construction that connects Sharif house to Raiwind. The event did not significantly disturb the stock market and was insignificant for both the 02 days and 05 days event windows.

\section{NAB Registered FIR against Hussain Haqqani}

According to the news of "Pakistan Today" on 13 Mar 2018, The FIA Registered a case against former Pakistan's Ambassador, Hussain Haqqani, in a corruption case that accused him of illegally using a secret fund $\$ 7.2$ million. The stock market didn't respond to this corruption event and shows an insignificant result.

\section{Chairman Karachi Stock Exchange (KSE) Arrested In Fake Account Case}

According to the news of "The News" on 06 Jul 2018, Federal Investigation unit (FIA) arrested the Close Friend of PPP Co-Chairman, Asif Ali Zardari and the chairman of Karachi Stock Exchange (KSE), Hussain Lawai in the case of money laundering through 29 fake bank accounts. The money laundering scam involved laundering of Rs. 35 billion in Sindh through various bank accounts. Asif Ali Zardari and his sister, Faryal Talpur, were also accused of using these "benami" accounts. The market was efficient and showed an insignificant relationship in both the $02 \& 05$ days event window.

\section{Zardari detention warrants issued for money laundering}

According to the news of "DAWN" on 17 Aug 2018, a banking Court issued a non-bailable arrest warrant to the Former President of Pakistan and PPP Co-Chairman, Asif Ali Zardari 
and 15 other accused in a fake bank account case. The case was regarding money laundering of 35 billion through fake bank accounts maintained in Summit Bank, Sindh Bank and UBL. The statistical $t$ value shows that this event has a significant positive impact on the stock market in both the short and long run.

\section{NAB Arrests Qaiser Abbas in Nandipur Corruption Case}

According to the news of "The Dawn" on 31 Aug 2018, an official of WAPDA, Qaiser Abbas was arrested by the NAB in the Corruption Case of Nandipur Power Project. The accused person was alleged of stealing furnace oil worth $220 \mathrm{~m}$ from the NandiPur Power Project. The effect of this event was positive for the stock market because the stock market was already experiencing negative returns throughout the week but the negativity reduced after this event.

\section{Court Order to seize the property of Ex-Finance Minister Ishaq Dar}

According to the news of "Pakistan Today" on 02-Oct-2018, accountability court ordered to seize and auction all the assets of Ex-Finance Minister and PML-N member, Mr. Ishaq Dar in the Corruption case of assets beyond the income petition filed by NAB. The Corruption case was worth Rs. 831m (Approx) of assets acquired by the Ex-Finance Minister which is not justifiable with his income. Reaction of this Corruption event was that the stock market crashed, the $t$ value for 02 and 05 days event widow both show significantly negative effect on the stock exchange.

\section{NAB Arrest Former Chief Minister Punjab Mian Shahbaz Sharif in Ashiana Housing Society Corruption Case}

According to the news of "Pakistan Today" on 05 Oct 2018, Former Chief Minister Of Punjab was arrested by NAB for his alleged involvement in the Ashiana Housing Scam which was worth Rs. 14 Billion. It is the case of illegal allotment of Housing Scheme contract to the Paragon Housing Society by canceling the contract of Lateef \& Sons Contractors in 2013. The event has a negative impact for both the even windows but it is significant for the short span and insignificant for the long span.

\section{Master Mind CFO Omni Group Arrested in Mega Money Laundering Corruption Case}

According to the news of "The News" dated 24 Oct 2018, Interpol arrested the Chief Financial Officer (CFO) of the Omni Group, Aslam Masood, from Jeddah following a red warrant issued by FIA. Masood Aslam was accused of opening fake accounts in various banks with the names of different people. The copies of CNIC were used without their consent for the purpose of money laundering. The effect of this event is insignificant in both the 02 and 05 days event windows. 


\section{CEO M/s. Hydrotech System Moid Faruki Arrest in Clean Drinking Water (CDWA)}

According to the news of "DAWN" on 13 Nov 2018, NAB arrested the Chief Executive Officer of HYDROTECH System, Moid Faruki. He was arrested in the case of Clean Drinking Water (CDWA) projects of April 2006. The project was that each union council will have a water filtration plant installed. The statistical result shows that this corruption event is insignificant for the $02 \& 05$ days event window.

\section{Five Others along with NICL Chairman Convicted for Fraud}

According to the news of "DAWN" dated 08 Dec 2018, along with five other, Ayaz Khan, former chairman of National Insurance Company Limited (NICL) were sentenced to 7 years' imprisonment due to corruption cases. The statistical result shows the significant positive value in event window 05 , while insignificant value found in event window 02.

\section{Khawaj Brothers Convicted for Fraud of Housing Society}

According to the news of "Pakistan Today" dated 11 Dec 2018, based on Paragon Housing Society Corruption Scam, PML-N MNA Khawaja Saad Rafique and Salman Rafique were arrested by NAB. The arrest order was given by Lahore High Court. The Statistical results show a negative effect in both the $02 \& 05$ days event window. However, the stock market reacted significantly only in the two day event window and became insignificant in the five day event window.

\section{Nawaz Sharif get \& Year Imprisonment in AL-Azizia Mills Corruption Case}

According to the news of "DAWN" dated 24 Dec 2018, Ex-Prime Minister of Pakistan and PML-N Leader, Mian Muhammad Nawaz Sharif was found guilty in the corruption case of AL-Azizia Steel Mills Company (ASCL) and Hill Metals Establishment (HME). As Nawaz Sharif was unable to provide the money trial of establishing both the foreign companies, he was sentenced to 7 years imprisonment and was imposed a fine of Rs. 1.5 billion and 25 millions in both the cases,. The statistical results show the insignificant but negative $t$ value in the 2 day window and significantly negative relationship between this event and stock market for the 5 day window.

\section{PTI Senior Leader and MNA Aleem Khan Arrested in Case of Asset beyond the Income}

According to the news of "The News" dated 06 Feb 2019, NAB arrested PTI Leader and Punjab minister, Aleem Khan in the Corruption case of asset beyond means and offshore companies. This political corruption event disturbed stock market performance negatively in both the event windows. Investors may have reacted negatively in the stock market because it was the first corruption case that involved a minister from the new government whose mission was to eradicate corruption. 


\section{Agha Siraj Durrani Arrested by NAB in Corruption Cases}

According to the news of "DAWN" dated 20 Feb 2019, NAB arrested the speaker of Sindh assembly and leader of PPP in three corruption cases pertaining to illegal appointment of 352 individuals in government positions, assets beyond means and embezzlement of funds in construction of MPA Hostel and construction of Sindh Assembly building. The effect of this corruption event is insignificant on the stock market.

\section{Discussion \& Conclusion}

The importance of the stock market coupled with the increased volatility makes investigation of stock market movements a crucial topic that requires utmost attention. This paper studies the impact of political and institutional corruption events on Karachi Stock Exchange. For this, twenty mega corruption cases are selected from reputable daily news papers namely Dawn, The Nations, Times, The News and Pakistan Today. Furthermore, the data of Pakistan Stock Exchange (PSX) daily return was obtained for the period of January 2011 to February 2019. Mean Adjusted Return Model t-values are calculated for 02 days and 05 days before and after the event occurred.

The above mentioned analysis shows that the results are mixed, some events are negatively impacting the stock exchange, some have a positive impact whilst others have no significant impact on the stock exchange. However, we can also see that eleven out of twenty corruption events have a significant impact on the stock exchange, while the other nine have an insignificant impact. Moreover, based on the two day event window results, we can see that eight events have a significant and negative effect on the stock market while only three have a significantly positive impact the stock market. Similarly, based on the five day event window, nine corruption events negatively impact the stock market while the other two have a positive effect on the stock market. Therefore, since most of the corruption events have a significant and negative impact on the stock exchange, we may conclude that political and institutional corruption events negatively impact the stock market.

Our findings are in compliance with former literature. Niederhoffer (1971) concluded that global events have a significant impact on the S\&P Index. Likewise, Chan and Wei (1996) studied how the volatility of Hong Kong stock exchange is impacted by political news. They report that there is a correlation between unfavorable political news and Hang Seng Index. Moreover, stock market volatility increased due to political news regardless of whether the stock is of a blue or red chip company. Recently, Gul et al. (2013) studied the impact of political instability on stock prices. They selected 14 insurance and banking listed companies and applied paired sample T-test statistics to analyze the relationship. They also found that there is a significant negative relationship between political instability and stock prices.

We suggest that investors and portfolio managers should be prudent towards their investment decisions during times of uncertainty. Especially, risk averse investors should take precautionary steps such as hedging strategies to avoid unwanted losses. Moreover, 
future research can investigate the problem further and try to understand why some corruption events have no impact, some have positive and some have a negative impact on the stock market. Therefore, for future research we recommend that a more qualitative approach needs to be taken.

\section{References}

Ayaydın, H., \& Baltacı, N. (2013). Corruption, banking sector, and stock market development: A panel data analysis. The Journal of Academic Social Science Studies, 6(4), $125-142$.

Barro, R. J., \& Lee, J.-W. (1994). Sources of economic growth. In Carnegie-rochester conference series on public policy (Vol. 40, pp. 1-46).

Beaulieu, M.-C., Cosset, J.-C., \& Essaddam, N. (2005). The impact of political risk on the volatility of stock returns: The case of Canada. Journal of International Business Studies, 36(6), 701-718.

Bilson, C. M., Brailsford, T. J., \& Hooper, V. C. (2002). The explanatory power of political risk in emerging markets. International Review of Financial Analysis, 11(1), 1-27.

Bin, L. (2015). Political leadership events and stock market reactions: Evidence from the Greater China Region. Journal of Accounting and Finance, 15(8), 81-94.

Chan, Y.-c., \& Wei, K. J. (1996). Political risk and stock price volatility: The case of Hong Kong. Pacific-Basin Finance Journal, 4(2-3), 259-275.

Chua, C. L., \& Tsiaplias, S. (2019). Information flows and stock market volatility. Journal of Applied Econometrics, 34(1), 129-148.

Collins, J. D., Uhlenbruck, K., \& Rodriguez, P. (2009). Why firms engage in corruption: A top management perspective. Journal of Business Ethics, 87(1), 89-108.

Cuervo-Cazurra, A. (2008). Better the devil you don't know: Types of corruption and FDI in transition economies. Journal of International Management, 14(1), 12-27.

Cutler, D. M., Poterba, J. M., \& Summers, L. H. (1989). What moves stock prices? Journal of Portfolio Management, 15, 4-11.

DAWN. (2017). Market closes flat after wild roller-coaster triggered by panamagate verdict (2019). Retrieved from https : / /www . dawn. com/news / 1348194

Egger, P., \& Winner, H. (2005). Evidence on corruption as an incentive for foreign direct investment. European Journal of Political Economy, 21(4), 932-952.

Glosten, L. R., \& Milgrom, P. R. (1985). Bid, ask and transaction prices in a specialist market with heterogeneously informed traders. Journal of Financial Economics, 14(1), 71-100.

Gul, S., Khan, M. T., Saif, N., Rehman, S. U., \& Roohullah, S. (2013). Stock market reaction to political events (Evidence from Pakistan). Journal of Economics and Sustainable Development, 4(1), 165-174.

Gupta, R., Lau, C. K. M., Liu, R., \& Marfatia, H. A. (2019). Price jumps in developed stock markets: The role of monetary policy committee meetings. Journal of Economics and Finance, 43(2), 298-312. 
Hassan, S. A., Mahmood, A., Ahmed, A., \& Abbas, S. F. (2014). Impact of terrorism on Karachi stock exchange: Pakistan. Journal of Basic and Applied Scientific Research, 4(7), 182-191.

Irshad, H. (2017). Relationship among political instability, stock market returns and stock market volatility. Studies in Business and Economics, 12(2), 70-99.

Li, J., Li, G., \& Zhou, Y. (2015). Do securitized real estate markets jump? International evidence. Pacific-Basin Finance Journal, 31, 13-35.

Mohtadi, H., \& Agarwal, S. (2001). Stock market development and economic growth: Evidence from developing countries. On line Available at: http//www. uwm. edu/mohadi/PA-4-01. pdf.

Niederhoffer, V. (1971). The analysis of world events and stock prices. The Journal of Business, 44(2), 193-219.

Perveen, S., \& Rahman, M. (2017). Impact of fiscal and monetary policies on stock market performance: An empirical study of Pakistan stock exchange. Journal of Finance and Economics Research, 3(2), 2-23.

Rawat, A. S., \& Arif, I. (2018). Does geopolitical risk drive equity price returns of BRIC economies? Evidence from quantile on quantile estimations. Journal of Finance and Economics Research, 3(2), 24-36.

Ross, S. A. (1989). Information and volatility: The no-arbitrage martingale approach to timing and resolution irrelevancy. The Journal of Finance, 44(1), 1-17.

Shleifer, A., \& Vishny, R. W. (1993). Corruption. The Quarterly Journal of Economics, 108(3), 599-617.

Voyer, P. A., \& Beamish, P. W. (2004). The effect of corruption on Japanese foreign direct investment. Journal of Business Ethics, 50(3), 211-224. 